Beata Karpińska-Musiał

Uniwersytet Gdański

lingbet@ug.edu.pl

Izabela Orchowska

Uniwersytet im. Adama Mickiewicza w Poznaniu

izaorch@amu.edu.pl

\title{
PROFESJONALIZM NEOFILOLOGA JAKO NAUCZYCIELA AKADEMICKIEGO WOBEC ZJAWISKA WIELODYSKURSYWNOŚCI W GLOTTODYDAKTYCE
}

The professionalism of the academic foreign language teacher in the face of multiple discourse competences in glottodidactics

The paper presents and discusses the concept of the discourse competence of an academic FL teacher as a researcher and a professional. For the sake of theoretical argument we also investigate the different kinds of discourse competence present in FL teaching and learning.

We propose that discourse competence should be the object of continuous development for teachers who aspire to develop their disciplinary and epistemological awareness: two components of a teacher's professionalism we consider indispensable in the teaching and learning process.

Keywords: FL teacher professionalism, discourse competence, disciplinary and epistemological awareness

Słowa kluczowe: profesjonalizm neofilologa, kompetencja dyskursywna, świadomość przedmiotowa i epistemologiczna 


\section{Wprowadzenie}

Profesjonalizm każdego nauczyciela warunkowany jest jego ciągłym samodoskonaleniem zawodowym. Doskonalenie to należy rozumieć wielowymiarowo, a przypadek glottodydaktyka jest szczególny ze względu na specyfikę procesu nauczania/uczenia się języków, interdyscyplinarny charakter kształcenia nauczycieli JO i jego osadzenie w perspektywie glottodydaktyki jako nauki empirycznej. Niniejszy artykuł skupia się na koncepcji kompetencji dyskursywnej jako przedmiocie samodoskonalenia nauczyciela akademickiego kształcącego przyszłych nauczycieli JO. Samokształcenie glottodydaktyka w zakresie jego kompetencji dyskursywnej należy wpisać w szerszy proces rozwijania jego świadomości przedmiotowej i epistemologicznej (Karpińska-Musiał i Orchowska, 2014). Albowiem tylko świadomy specyfiki swojej dyscypliny naukowej i specyfiki przedmiotu swego nauczania, jakim są i język nowożytny, i glottodydaktyka rozumiana jako przedmiot akademicki, jest on w stanie rozwijać kompetencję dyskursywną w taki sposób, aby ukierunkować swe działania komunikacyjne na konstruowanie wiedzy w dialogu z innymi naukowcami oraz studentami. Ponadto, w momencie przekształceń systemowych na polskich uczelniach wyższych, świadomy rozwój kompetencji dyskursywnej neofilologa - nauczyciela akademickiego - niejako warunkuje jego postawę krytyczną ${ }^{1}$ wobec założeń procesu bolońskiego oraz dyskursów naukowych i wielu innych obecnych w przestrzeni publicznej, a koniecznych do uwzględnienia w procesie planowania i realizacji prowadzonych przez siebie zajęć dydaktycznych.

\section{Od pojęcia dyskursu do pojęcia profesjonalizmu glottodydaktyka jako nauczyciela akademickiego}

Jak zauważa Klus-Stańska (2010: 144), terminem, który w uświadamianiu niejednoznaczności dydaktyki i praktyk społecznych z nią związanych odgrywa znaczącą rolę, jest termin dyskurs. Na gruncie glottodydaktyki konieczne jest zaproponowanie jego definicji, która mogłaby być punktem odniesienia w określaniu kompetencji dyskursywnej nauczycieli JO, a w szczególności nauczycieli akademickich odpowiedzialnych za proces ich kształcenia oraz za własne samokształcenie zawodowe. $Z$ kolei koncepcje profesjonalizmu nauczyciela, w tym nauczyciela JO, nieustannie ewoluują w danym społeczeństwie, gdyż wynikają

\footnotetext{
${ }^{1}$ Postawę krytyczną uznajemy za przejaw myślenia krytycznego, które np. w ujęciu Giroux (2005) i Góreckiej (2006) jest typem myślenia pozwalającym na rozwój intelektualny jednostki przez szersze i bardziej kompleksowe postrzeganie i interpretowanie rzeczywistości, niż ma to miejsce w przypadku myślenia potocznego.
} 
w dużej mierze z oczekiwań społecznych o dynamicznym charakterze i podatności na przemiany społeczne, kulturowe, instytucjonalne, ideologiczne i polityczne. Jak zauważyła Gołębniak (1998), dyskusja nad profesjonalizmem nauczycieli pojawia się najczęściej w przełomowych albo trudnych dla społeczeństwa momentach. Ostatnio znaczącą rolę w postrzeganiu nauczyciela akademickiego jako profesjonalisty odgrywają przemiany organizacyjne w polskiej edukacji związane $z$ procesem bolońskim, $w$ tym administracyjne, nomenklaturowe, formalizacyjne, proceduralne (Karpińska-Musiał, 2013), ale również takie zjawiska, jak rozwój nowoczesnych technologii i będący jego pokłosiem rozdźwięk międzypokoleniowy w podejściu do tych ostatnich.

Wracając do pojęcia dyskursu, jest ono ujmowane w bardzo różny sposób w naukach społecznych i humanistycznych. W niniejszym artykule staramy się zdefiniować to pojęcie tak, aby było ono funkcjonalne w szczególnym obszarze glottodydaktyki, jakim jest kształcenie i samokształcenie neofilologów. Spośród definicji dyskursu zaproponowanych na gruncie polskiej glottodydaktyki najbardziej operacyjna wydaje się nam definicja dyskursu jako całości wypowiedzi (jednego lub więcej mówców) traktowana jako odpowiadająca danej sytuacji komunikacyjnej (Wilczyńska i in., 2002: 320). Autorki tej koncepcji akcentują również fakt, że w ich ujęciu dyskurs stanowi całościowy układ odniesienia w formułowaniu oczekiwań, interpretacji i ocen. Wydaje nam się to szczególnie ważne z perspektywy neofilologa jako nauczyciela akademickiego, gdyż w swoich wypowiedziach aktywizuje on swoją kompetencję dyskursywną na trzech poziomach działalności: dydaktycznym, naukowo-badawczym i, szerzej, na poziomie funkcjonowania w kontekście społeczno-politycznym, z uwzględnieniem perspektywy interkulturowej.

Ponadto, jeśli przyjmiemy, że interesuje nas glottodydaktyczne podejście do dyskursu, to na pewno musimy uwzględnić założenia glottodydaktycznej perspektywy zadaniowej i przyjąć, że nauczyciel akademicki jest podmiotem wypowiedzi działającym społecznie, o złożonej i dynamicznej tożsamości. Jako taki nie tylko przyczynia się do rozwoju poznawczego swoich studentów, ale również konstruuje z nimi wspólnie relacje interpersonalne i reprezentacje rzeczywistości m.in. przez podejmowane przez siebie działania komunikacyjne i przejawy tzw. myślenia dyskursywnego. Z tym ostatnim mamy do czynienia wówczas, gdy wiedza osiągana jest stopniowo, na bazie uznanej wcześniej wiedzy za sprawą ogniw i operacji pośrednich, i jest ono inspirowane rozmową, dialogiem, dyskusją, wymianą argumentów, polemiką (Ostrowska, 2011: 260).

Z pojęciem dyskurs w przyjętej przez nas perspektywie łączy się bezpośrednio zjawisko dyskursywności pojęć, za pomocą których opisujemy świat. Sam dyskurs staje się wówczas interpretowalnym wydarzeniem, powiązanym ze społeczno-politycznym kontekstem, który w dyskursie się wyraża (Klus- 
Stańska, 2010: 146). Klus-Stańska wyróżnia tutaj z jednej strony dyskursy proponowane przez dydaktyków jako odpowiednie na lekcje, a z drugiej strony dyskursy dydaktyki jako subdyscypliny naukowej, w których uruchamia się refleksja dydaktyczna. Nas będą interesowały obie te płaszczyzny dyskursów, ale odniesiemy je do funkcjonowania dyskursywnego ${ }^{2}$ glottodydaktyków jako członków glottodydaktycznej wspólnoty dyskursu ${ }^{3}$, przy założeniu, że glottodydaktyka jest nauką autonomiczną o charakterze empirycznym.

Przechodząc natomiast do samego pojęcia profesjonalizmu nauczyciela akademickiego, należy go zgodnie z sugerowaną wyżej typologią rozpatrywać na trzech możliwych poziomach analizy: publicznym, naukowo-badawczym oraz ściśle dydaktycznym. Po pierwsze, na poziomie dyskursu publicznego (społeczno-politycznego), którego glottodydaktycy nie mogą ignorować ze względu na to, że stanowi on wyraz oczekiwań społecznych, koncepcja profesjonalnego nauczyciela łączy się przede wszystkim z jego efektywnością w zakresie spektakularnych wyników i sukcesów jego uczniów/studentów. Nie towarzyszy temu jednak z reguły refleksja nad kompetencjami nauczycieli, które znajdują się w centrum zainteresowania dyskursu naukowego. Na naukowobadawczym poziomie dyskursu adresowanego do specjalistów w zakresie kształcenia nauczycieli mamy do czynienia z modelami kompetencji nauczycielskich i z postulowaniem działań wpisujących się w paradygmat humanistyczny, konstruktywistyczny lub krytyczno-emancypacyjny (Sajdak, 2013). Trudno tutaj nie zgodzić się z Klus-Stańską (2009: 13), że w chwili obecnej na gruncie dydaktyki „,stoimy [...] przed koniecznością odejścia od metodycznej postulatywności na rzecz badań nad tym, co dzieje się w klasie szkolnej i jakiego rodzaju stanu umysłów możemy się spodziewać u absolwentów po tak zaprojektowanej edukacji". Szczególnie ważne jest, zdaniem przywołanej badaczki,

2 Funkcjonowanie dyskursywne glottodydaktyków obejmuje zarówno ich pragmatyczne działania komunikacyjne, jak i myślenie dyskursywne.

3 Odnosimy się tutaj do koncepcji wspólnoty dyskursu rozwiniętej przez Swalesa (1990), której istotę stanowią cele społeczne przyświecające jej członkom oraz posiadanie przez nich określonej kompetencji tworzenia i odbierania tekstów, stanowiących własność określonej wspólnoty (Duszak, 2002). Zdaniem Duszak, wspólnota może być w takim ujęciu definiowana przez typy dyskursów, które wykształca dla realizacji swoich celów społecznych, przy czym w ramach tej wspólnoty zachodzą różne stopnie członkostwa czy też wtajemniczenia w zasób wiedzy ogólnej i językowej. Jest to szczególnie widoczne wewnątrz wspólnoty glottodydaktycznej, obejmującej zarówno nauczycieli języków obcych, jak i pracowników naukowo-dydaktycznych, którzy stopniowo wchodzą w rolę naukowca przez nabywanie wiedzy specjalistycznej oraz rozwijanie ich kompetencji dyskursywnej, a także świadomości dyscyplinarnej i epistemologicznej (Karpińska-Musiał i Orchowska, 2014). 
Profesjonalizm neofilologa jako nauczyciela akademickiego wobec zjawiska...

zrozumienie tego, iż idea dydaktyki „skutecznej", wciąż obecna w potocznym dyskursie i sposobie myślenia o edukacji, może być w dyskursie naukowym poddana analizie krytycznej w celu ujawnienia zależności procesów nauczania od „,gry sił społeczno-politycznych, konfliktów interesów, wpływów biurokratyczno-administracyjnych".

W obszarze dyskusji odbywającej się na poziomie naukowo-badawczym warto skonfrontować ze sobą modele kompetencji nauczyciela proponowane przez pedagogów i glottodydaktyków, gdyż one wzajemnie się uzupełniają. I tak, w polskim dyskursie pedagogicznym dominuje przekonanie, że najistotniejszą sferę kształtowania profesjonalizmu nauczyciela stanowi sfera świadomego kontaktu z drugim człowiekiem (Grzybowski, 2006: 135). Jednocześnie KlusStańska postuluje konieczność badań dydaktycznych nad komunikacją w klasie szkolnej, i to już nie tylko na poziomie lingwistycznym, ale również społecznym. Jej zdaniem brakuje analiz dydaktycznych osadzonych w perspektywie społeczno-krytycznej, a zwłaszcza zapomina się, że w dyskursie edukacyjnym znajdują swoje bezpośrednie odbicie nie tylko teorie naukowe, ale także obecne w życiu społecznym opcje ideologiczno-polityczne (Klus-Stańska, 2010: 165). Poszerza to znacząco repertuar dyskursów, które powinien znać i którymi powinien operować dydaktyk jako nauczyciel akademicki.

Na poziomie dydaktycznej analizy profesjonalizmu nauczyciela, zwłaszcza w obrębie glottodydaktyki, wciąż punktem wyjścia są jego kompetencje językowe, przy czym lista pozostałych kompetencji ciągle się poszerza i jest mocno praktycznie zorientowana. Dla przykładu, Zawadzka (2004: 110-111) uznaje za niezbędne w pracy nauczyciela JO następujące kompetencje: językowe (specjalistyczne), psychopedagogiczne - obejmujące znajomość psychologii rozwojowej, kompetencję komunikacyjną oraz umiejętność współdziałania - kompetencje metodyczne, wychowawcze i stanowiące ich podstawę kompetencje moralne. Te ostatnie obejmować mają wychowanie w duchu wolności i demokracji, tolerancji, kształtowanie postaw tolerancji i akceptacji dla innych kulturowo, oraz umiejętność międzykulturowego nauczania. Badaczka wymienia dalej kompetencje organizacyjne oraz kompetencje innowacyjno-kreatywne, polegające na twórczym korzystaniu z informacji, umiejętności analizy problemów i twórczego ich rozwiązywania, a także myśleniu krytycznym i niestandardowym działaniu. Jak już sygnalizowałyśmy, w niniejszym artykule przyglądamy się profesjonalizmowi glottodydaktyka z perspektywy jego kompetencji dyskursywnej. Rozwój owej kompetencji powinien, zgodnie z naszą tezą, być skorelowany z rozwijaniem świadomości przedmiotowej i epistemologicznej glottodydaktyków, gdyż to one są filarem ich samokształcenia zawodowego (Karpińska-Musiał i Orchowska, 2014). Zarazem, jak słusznie podkreśla Górecka (2006), istotą dydaktycznej działalności glottodydaktyka w wymiarze 
akademickim jest także wdrażanie studentów do dyskursu naukowego. Można to czynić np. przez wprowadzanie meta-komentarzy natury epistemologicznej, mających zapewnić zgodność konstruowanej przez studentów refleksji z wymogami wywodu akademickiego, czy też przez działania mające pomóc studentom w bardziej efektywnym organizowaniu toku myślenia, np. dbanie o argumentacyjne nachylenie dyskusji dzięki zachęcaniu studentów do podsumowań lub parafrazowaniu własnych wypowiedzi. Istotną umiejętnością wartą uwagi są też działania zmierzające do tworzenia akademickiej wspólnoty dyskursywnej opartej na partnerskich relacjach, np. przez konstruowanie siebie jako partnera w dyskusji, czyli osobę poszukującą i otwartą na dialog.

Tytułem podsumowania roli wspomnianych trzech poziomów analizy dla formułowania definicji profesjonalizmu glottodydaktyka jako nauczyciela akademickiego, należy podkreślić, że powinien on łączyć w sobie cechy profesjonalizmu zarówno naukowca (poziom badawczo-naukowy), jak i dydaktyka (poziom dydaktyczny). W ujęciu Wilczyńskiej i Michońskiej-Stadnik (2010: 82) miarą profesjonalizmu naukowca są m.in.: „,wysokie osobiste zaangażowanie, pasja poznawcza, szczególny typ rzetelności i uczciwości poznawczej w dążeniu do sukcesów naukowych". Stawia to przed nim, zdaniem cytowanych autorek, wysokie wymagania w zakresie wiedzy specjalistycznej (kompetencje merytoryczne) i kompetencji metodologicznych, a także wymogów etycznych. Dochodzi do tego konieczność wypracowania u siebie takich cech, jak postawa refleksyjna, zdolność do syntezy i tworzenia ujęć globalnych, stosowny dystans do wyznawanych poglądów i teorii, zdolność do działań intelektualnych i dialogu naukowego, a także wysokie umiejętności komunikacyjne w zakresie swojej specjalności. Te ostatnie powinny się przejawiać w jego funkcjonowaniu dyskursywnym. Co istotne, nauczyciel akademicki nie może ograniczać się do spełniania wspomnianych wymogów jedynie we własnej działalności naukowej, ale ma za zadanie wdrażać do rzetelności i uczciwości poznawczej swoich studentów, do czego stwarza okazję przestrzeń jego działalności dydaktycznej.

\section{Pojęcie epistemy, zarządzanie wiedzą i wyzwania nowoczesności refleksyjnej wobec systemu kształcenia w glottodydaktyce}

Dyskusja o profesjonalizmie akademickim nie może pominąć zjawiska zmian paradygmatycznych oraz ideowych, które zachodzą w ostatnich dziesięcioleciach w humanistyce. Zmiany w metodach, traktowaniu badań i ich zakresie, a także dualizm, który pojawia się w naukach o edukacji, nie pozostają bez wpływu na modelowanie profilu akademika profesjonalisty. Dualizm, o jakim mowa, ma wiele interpretacji, ale kluczowy dla argumentacji na temat wielodyskursywności jest rozdział pomiędzy dwoma typami funkcjonowania poznawczego, które 
Bruner (1986) dzieli na paradygmatyczny i narracyjny. Można ten podział odnieść analogicznie do zakorzenionego już silnie w naukach poznawczych dualizmu między wiedzą deklaratywną a proceduralną, które dyktują określone definicje i kierunki procesów poznawczych (np. Ryle, 1970/1949; Anderson, 1998/1995; Sternberg, 2000; Stemplewska-Żakowicz, 1996). Narracyjny charakter tworzenia znaczeń, który Klus-Stańska (2002) uważa za podstawę skutecznej i psychologicznie motywującej dydaktyki, skutkującej tworzeniem postaw autorefleksyjnych zarówno wśród uczniów, jak i nauczycieli, zasadniczo wypływa ze zwrotu kulturowego i językowego w humanistyce końca XX w. Przykładowo, paradygmat modernizacji refleksyjnej w kształcie, w jakim opisuje go Lash (2009), stawia przed uczestnikami układu glottodydaktycznego, jedno istotne wyzwanie: konieczność przetwarzania wiedzy uzyskanej wskutek uczenia się. Nie oczekuje się jednak, a przynajmniej nie powinno, typowo scholastycznego utrwalenia, w oderwaniu od procedur zastosowania, a raczej rekonstrukcji w oparciu o osobiste doświadczenie. Klus-Stańska pisze tu o „personalizującej obróbce” wiedzy, odnosząc się do podziału wiedzy na osobistq i publicznq, z których ta pierwsza zdobyła w dyskursie metodycznym u progu nowego millenium wiodącą pozycję dla efektywności procesów edukacyjnych (Klus-Stańska, 2002: 192). Elementami takiej „obróbki” stały się umiejętność selekcji, syntezy, analizy, a także po prostu wyboru informacji i ich odniesienia do osobistych doświadczeń, poglądów, własnego rozumienia. Fakt ten wynika także z rosnących wpływów podejścia konstruktywistycznego w humanistyce, w którym naczelną zasadą determinującą i określającą pojęcia wiedzy, nauki, uczenia się i dyskursu jest ich wytwarzanie, współkonstruowanie oraz produkowanie znaczeń w kontekście. W ten sposób w zmianach w podejściu do nauczania i uczenia się można odnaleźć bezpośrednie referencje do dyskursywnego - inaczej narracyjnego - charakteru rzeczywistości edukacyjnej.

Dla naszego wywodu istotny jest sam proces doraźnego współtworzenia światów edukacyjnych nauczycieli. W opinii Szempruch (2013: 63), nie sposób już pominąć w procesach tworzenia koncepcji kształcenia nauczycieli wielości kontekstów zmieniającego się świata, a raczej światów, w których nauczyciele operują. Czymś, co szczególnie wpływa na tę różnorodność, są - jak przywołuje ta autorka - „światy indywidualnych poglądów” nauczycieli, co koreluje silnie $z$ ideą teorii indywidualnych (subiektywnych) nauczycieli (Zawadzka, 2004: 105), a w kontekście teorii narracji jako typu myślenia i wiedzy - z wiedzą osobistą. Te poglądy powstają w dwóch obszarach lub wymiarach: treści edukacyjnych i ich realizacji oraz osobistych doświadczeń osób uczących się, do których nauczycieli trzeba także zaliczyć, jeśli traktujemy układ glottodydaktyczny kompleksowo i zgodnie z założeniami całożyciowego uczenia się.

Niezależnie od możliwych interpretacji ponowoczesna rzeczywistość mówi nam o wiedzy budowanej $w$ doświadczeniu edukacyjnym poszczególnych 
osób. Takie podejście koreluje silnie ze zjawiskiem wielodyskursywności. Glottodydaktyka wydaje się być szczególnie podatnym gruntem dla tej perspektywy, gdyż stanowi pole przekazu wartości zawartych w dyskursach biorących udział w kształceniu (i stanowiących przedmiot tego kształcenia). Obecność w glottodydaktyce dyskursu jako podstawowego obiektu nauczania pozwala na czynienie referencji do pojęcia epistemy w analizie dyskursu. Chociaż koncepcja ta leży blisko znaczenia Kuhnowskiego paradygmatu, Foucault określa epistemę jako fundamentalne kody danej kultury, czyli to, co rządzi jej językiem, jej formami poznawania, sposobami wymiany, technikami, wartościami, hierarchią działań (Foucault, 2005). Eksplikacja epistemy następuje przez opis korespondencji słów i rzeczy oraz ukazanie ich porządku, co wprost czyni z niej narzędzie do analizy wielodyskursywności, o której traktuje ten artykuł. Tym bardziej, jeśli traktujemy epistemę jako klucz do rozpoznania specyfiki danego obszaru dyskursywnego - czy to będzie metodologia nauk, metodyka nauczania języka obcego, dyskurs klasowy albo dyskurs środowiskowy. Analiza praktyk dyskursywnych pozwala podmiotowi, jak twierdzi Foucault, odnieść się intencjonalnie i refleksyjnie do przedmiotu dyskursu, a przy okazji sam podmiot tym dyskursem się staje (jego uczestnikiem, współtwórcą i źródłem). W takiej optyce widzimy, że mówiąc o wielodyskursywności glottodydaktyki, poruszamy się po obszarze zarówno sposobów mówienia o profesjonalizmie nauczyciela akademickiego, jak i o praktykach dyskursywnych, w których on sam jest zanurzony.

Do znaczenia epistemy w dyskusji nad podnoszeniem profesjonalizmu akademickiego nawiązuje projekt epistemologii opisany przez Theodore Adorno. Adorno zajmował się przede wszystkim postawą krytyczną, a potrzebę myślenia krytycznego jednostki motywował szerokim spektrum uwarunkowań historycznych, politycznych i społecznych, w jakich żyje. To, co z filozofii Adorna jednak epatuje najbardziej i jest nośne dla kontekstu epistemologicznej świadomości nauczycieli, to konieczność uwzględniania kontekstu zdarzeń, pewna płynność interpretacji oraz bezwzględny związek poznania ze ścieraniem się relacji, zależności, doświadczeń oraz zmysłowych, a nie tylko racjonalnych (czyli tylko obiektywnych) przeżyć. Powołując się na Adorna, można stwierdzić, że jak każde inne doświadczenie związane z relacją podmiotów (a są nimi uczestnicy dialogu edukacyjnego), każda lekcja - a tym bardziej lekcja języka obcego - jest bliska pojęciu przeplotu: „splotu przesądów, poglądów, impulsów, auto-korektur, antycypacji i przejaskrawień" (Pijanowski, 2012). Cóż bardziej modelowo obrazuje wielość dyskursów potencjalnie obecnych w działaniach edukacyjnych, jeśli przyjąć za punkt wyjścia obecność wspomnianego wyżej narracyjnego stylu poznawczego?

Relacja między nauczycielem a uczniami podczas zdarzenia klasowego jest właśnie nieustannym wchodzeniem w dialog z innymi podmiotami, ustosunkowywaniem się do tego, co nowe lub już powiedziane wcześniej, reinterpretacją 
nowego w świetle starego lub odwrotnie. Porównanie tej epistemologii do eseistyki, jako struktury poznania eseistycznego ${ }^{4}$, niesie niewątpliwie szerokie implikacje, których analiza wykracza poza kontekst naszej argumentacji. Pozwala jednak przyjąć za pewnik fakt, że lekcja-dzieło o wielu obliczach, na wzór eseju, nie może być zamknięta na szeroki kontekst społeczno-kulturowy (stąd potrzeba analizy profesjonalizmu nauczyciela także z poziomu publicznego, jak wyżej), łączący sprzeczności z oczywistościami, nawiązujący do wspólnotowości i indywidualizmu, powtórzeń i innowacji, nieustająco dziejącej się w ten sposób refleksji i współprodukcji dyskursów. Profesjonalizm nauczycieli akademickich w obszarze glottodydaktyki jako nauki empirycznej sytuuje się zatem właśnie na styku osobistych doświadczeń (teorii/poglądów indywidualnych/subiektywnych), kontekstów językowo-społeczno-kulturowych oraz przez umiejętne stosowanie w tych stycznych punktach metody zarządzania różnymi typami wiedzy. Oba typy dążenia do mistrzostwa - jako dydaktyka i jako naukowca - nie muszą się wykluczać, a wręcz powinny się uzupełniać. $W$ ten sposób akademicki profesjonalizm może być rozumiany jako sztuka „nieustannego konstruowania wiedzy procesualnej na podstawie wykształcenia akademickiego" (Szempruch, 2013: 63). Potwierdza to nasze wcześniejsze wnioski, że profesjonalizm współczesnego nauczyciela-badacza wymaga rozwijania nie tylko świadomości przedmiotowej, ale także epistemologicznej.

\section{Kompetencja dyskursywna nauczyciela akademickiego a zjawisko wielodyskursywności w glottodydaktyce}

Dyskursywność, a raczej postulowaną przez nas wielodyskursywność w praktyce nauczania/uczenia się JO, rozumiemy jako współwystępowanie w glottodydaktycznej wspólnocie dyskursu wielu typów i gatunków dyskursu. W kontekście nauczania/uczenia się JO osoby uczące się i nauczające mają do czynienia ze współwystępowaniem następujących ich typów:

1. dyskurs dnia codziennego jako przedmiot nauczania-uczenia się, przy czym ten dyskurs będzie różny w zależności od uczniów, poziomu ich zaawansowania i celów kształcenia akademickiego;

2. dyskurs specjalistyczny jako przedmiot N/U specjalistycznego, np. dyskurs naukowy w ramach którego można wyróżnić takie gatunki tekstów naukowych, jak: artykuł, studium, rozprawa, monografia, referat,

\footnotetext{
${ }^{4}$ Sendyka określa ten rodzaj epistemologii poznaniem, które „nie obywa się [...] bez pojęć: ich znaczenie nie jest jednak dane apriorycznie, ale wykonstruowane w toku relacji, interrelacji, wzajemnych zależności, starć, aspektowych przesunięć, zmian punktów obserwacji” (Sendyka, 2006: 292).
} 
wykład, recenzja, streszczenia (Kozłowska, 2007: 32), obecny jest on przede wszystkim w filologicznym kształceniu akademickim;

3. dyskurs szkolny i/lub dydaktyczno-akademicki, którym posługują się nauczyciele, zwracając się do swoich uczniów/studentów w celu wprowadzenia materiału będącego przedmiotem nauczania/kształcenia, ustosunkowywania się do i oceny produkcji studentów; jednocześnie dyskurs dydaktyczno-akademicki cechuje ukierunkowanie na cele poznawcze i naukowy sposób myślenia oraz interpretowania rzeczywistości;

4. dyskurs oświatowy/oświatowo-administracyjny i dyskurs aktów normatywnych, w tym rozporządzenia ministerialne (m.in. teksty związane z Krajowymi Ramami Kwalifikacji i procesem bolońskim), dokumenty wydawane przez Kuratorium Oświaty, których lektura i interpretacja odbywają się poza lekcją szkolną, ale wpływają na jej planowanie i przebieg;

5. dyskurs publiczny, który z jednej strony wpływa na reprezentacje osób uczących się i nauczających, a z drugiej strony może być też przedmiotem nauczania/uczenia się; $w$ tym sensie dyskurs publiczny, podobnie jak i oświatowo-administracyjny, stanowią przykłady dyskursów użytkowych dla nauczycieli, a zarazem opisowych i normalizujących; znajomość tych dyskursów jest warunkowana własną świadomością zanurzenia sytuacyjnego, społecznego i kulturowego nauczycieli, ich wiedzą ogólną i/lub merytoryczną, ale także wpisaniem owych praktyk dyskursywnych w dynamikę tożsamościową uczestników komunikacji.

Z kolei wielodyskursywność w glottodydaktyce jako nauce, naszym zdaniem, oznacza:

1. wielość form komunikowania się wewnątrz glottodydaktycznej wspólnoty dyskursu (w warstwie językowej i konceptualnej, na poziomie gatunków dyskursu oraz kulturowych i indywidualnych stylów komunikacyjnych);

2. wielość znaczeń i interpretacji roli i funkcji nauczyciela w dyskursach naukowym, publicznym i oświatowym i ich dynamiczny charakter;

3. wielość koncepcji a nawet paradygmatów i quasi-paradygmatów współwystępujących i/lub współtworzonych obszarze badawczym glottodydaktyki; łączy się ona z wieloparadygmatycznością tej dyscypliny naukowej i zarazem tworzy dyskurs naukowy, w którym zanurzony jest profesjonalista już nie tylko jako nauczyciel, ale przede wszystkim jako badacz zdolny werbalizować własne i cudze stanowiska epistemologiczne w komunikacji akademickiej ${ }^{5}$.

\footnotetext{
${ }^{5}$ Komunikację akademicką rozumiemy szerzej niż komunikację naukową, gdyż obejmuje ona zarazem komunikację między naukowcami, jak i między tymi ostatnimi a studentami w kontekście akademickim.
} 
Profesjonalizm neofilologa jako nauczyciela akademickiego wobec zjawiska...

Uwzględnienie zjawiska wielodyskursywności w nauczaniu/uczeniu się JO i w glottodydaktyce jako nauce wskazuje zatem na powiązanie kompetencji dyskursywnej nauczyciela akademickiego z procesem rozwijania jego świadomości przedmiotowej i epistemologicznej, a świadomy tej zależności glottodydaktyk efektywniej kieruje procesem swojego samodoskonalenia zawodowego i ukierunkowuje go na konkretne cele kształcenia.

\section{Podsumowanie}

Kompetencja dyskursywna nauczyciela akademickiego, która stanowi o jego statusie jako profesjonalisty, jest zatem pojęciem niezwykle złożonym. Oznacza nie tylko opanowanie i rozumienie bogatego repertuaru gatunków dyskursu celem komunikacji, w tym sztukę dekodowania i interpretacji dyskursów naukowego, publicznego i oświatowego w zakresie kształcenia językowego i szeroko rozumianej edukacji, ale także umiejętność ich kompleksowej analizy językoznawczej, metajęzykowej, metagatunkowej i metaglottodydaktycznej. Co więcej, oznacza także umiejętność ich doboru, definiowania i prezentowania jako przedmiotu nauczania/uczenia się oraz jako wyznacznika danego stanowiska epistemologicznego.

Wreszcie, kompetencja dyskursywna glottodydaktyka profesjonalisty powinna pozwolić mu na współuczestniczenie w funkcjonowaniu glottodydaktycznej wspólnoty dyskursu - i to zarówno przez upowszechnianie wiedzy naukowej na temat nauczania/uczenia się JO, jak i poszerzanie własnej wiedzy dzięki lekturze publikacji innych specjalistów. Kluczowe dla funkcjonowania w rodzimej wspólnocie glottodydaktycznej jest jednocześnie zaznajomienie się z dyskursem oświatowo-administracyjnym, wprowadzającym określone ramy organizacji pracy, a także z dyskursem publicznym (ideowym). Obowiązkiem profesjonalisty jest ich rozpoznanie, krytyczna ocena oraz samookreślenie się na ich tle.

Odrębną sprawą, wymagającą osobnej analizy, może być fakt, że nawet przy tak rozbudowanej świadomości wielodyskursywności mówi się o „dyskursywnej walce o znaczenia" prowadzonej przez różne metanarracje, czyli różne „wersje rzeczywistości”. Przy całej idei agonistycznego „wsłuchiwania się w cudze głosy", trzeba przyznać rację Foucault w jego definiowaniu wiedzy jako władzy oraz odnajdywaniu w wielodyskursywności zjawisk różnicowania, wykluczania i normalizowania. Jako przykład warto przywołać dyskursy Krajowych Ram Kwalifikacji (Karpińska-Musiał, 2013) lub kontrowersyjny w humanistyce dyskurs neoliberalny. Oba wnoszą zgodną z teoriami wieloparadygmatyczności zmianę, jednak najpierw - z racji silnych tendencji normalizujących i zbyt szybkiej, a nieprzystawalnej do nich bezpośrednio specyfiki kształcenia akademickiego - przechodzą przez fazę oporu w środowisku. Ujęcie dyskursu neoliberalnego jako 
jednego z dodatkowych dyskursów w układzie glottodydaktycznym stanowi obecnie ciekawe pole do dalszych badań i analiz, które mogą zostać poruszone w naszych kolejnych publikacjach.

\section{BIBLIOGRAFIA}

Anderson J. R. 1998 [1995]. Uczenie się i pamięć. Warszawa: Wydawnictwo Szkolne i Pedagogiczne.

Bruner, J. S. 1986. Actual minds, possible worlds. Cambridge: Harvard University Press. Duszak, A. 2002. „Języki, kultury, wspólnoty” (w) Język rodzimy a język obcy. Komunikacja, przekład, dydaktyka (red. A. Kopczyński, U. Zalewska-Okrutna). Warszawa: Wydawnictwo Uniwersytetu Warszawskiego: 7-22.

Foucault, M. 2005. Słowa i rzeczy. Archeologia nauk humanistycznych. Gdańsk: Słowo Obraz Terytoria.

Giroux, H. A. 2005. „The Terror of Neoliberalism: Rethinking the Significance of Cultural Politics". College Literature 32(1): 1-19.

Gołębniak, B. D. 1998. Zmiany edukacji nauczycieli. Wiedza - biegłość - refleksyjność. Toruń/Poznań: Edytor.

Górecka, J. 2006. Développer la pensée critique à travers les discussions en langue étrangère. Kraków: FLAIR.

Grzybowski, P. P. 2006. „Profesjonalizm nauczyciela - a cóż to takiego?”. Rocznik Pedagogiczny 29: 31-137.

Karpińska-Musiał, B. 2013. „KRK dla szkolnictwa wyższego w Polsce jako okazja do przekształceń w glottodydaktyce. Komunikat z wstępnych badań na temat formułowania i walidacji efektów kształcenia w ramach reformy szkolnictwa wyższego". Neofilolog 40(1): 79-92.

Karpińska-Musiał, B., Orchowska, I. 2014. „Świadomość przedmiotowa i epistemologiczna nauczyciela - refleksyjnego praktyka z perspektywy polskiej glottodydaktyki". Neofilolog 43(1): 25-38.

Klus-Stańska, D. 2002. „Narracje w szkole” (w) Narracja jako sposób rozumienia świata (red. J. Trzebiński). Gdańsk: GWP: 189-220.

Klus-Stańska, D. 2010. Dydaktyka wobec chaosu pojęć i zdarzeń. Warszawa: Wydawnictwo Akademickie ŻAK.

Kozłowska, Z. 2007. O przekładzie tekstu naukowego (na materiale tekstów językoznawczych). Warszawa: WUW.

Ostrowska, U. 2011. „Dyskurs w edukacji akademickiej”. Przeglqd Pedagogiczny 1(25): 258-266.

Pijanowski, P. 2012. „Esej o metodzie, esej jako metoda. Problematyka epistemologiczna w Minima Moralia Theodora W. Dorno". Polisemia 2(9): 2082-3053. http://www.polisemia.com.pl/numery-czasopisma/numer-2-2012-9/esej-o-m etodzie-esej-jako-metoda-problematyka-epistemologiczna-w-minima-moralia -theodora-w-adorno DW 11.11.2014.

Ryle, G. 1970 [1949]. Czym jest umyst? Warszawa: PWN. 
Profesjonalizm neofilologa jako nauczyciela akademickiego wobec zjawiska...

Sajdak, A. 2013. Paradygmaty kształcenia studentów i wspierania nauczycieli akademickich. Teoretyczne podstawy dydaktyki akademickiej. Kraków: Impuls.

Sendyka, R. 2006. Nowoczesny esej. Studium historycznej świadomości gatunku. Kraków: Universitas.

Stemplewska-Żakowicz, K. 1996. Osobiste doświadczenie a przekaz społeczny. O dwóch czynnikach rozwoju poznawczego. Wrocław: Leopoldinum.

Sternberg, R. J. 2000 „Intelligence and Wisdom” (w) Handbook of Intelligence (red. R. J. Sternberg). Cambridge: Cambridge University Press: 631-649.

Swales, J. 1990. Genre analysis: English in academic and research settings. Cambridge: Cambridge University Press.

Szempruch, J. 2013. Pedeutologia. Studium teoretyczno-pragmatyczne. Kraków: Impuls.

Trzebiński, J. 1981. Twórczość a struktura pojęć. Warszawa: PWN.

Wilczyńska, W., Górecka, J., Nowicka, A. 2002. „Słowniczek najważniejszych terminów dotyczących autonomizacji” (w) Autonomizacja w dydaktyce języków obcych. Doskonalenie się w komunikacji ustnej (red. W. Wilczyńska). Poznań: Wydawnictwo Naukowe UAM: 317-335.

Wilczyńska, W., Michońska-Stadnik, A. 2010. Metodologia badań w glottodydaktyce. Wprowadzenie. Kraków: Avalon/Flair.

Zawadzka, E. 2004. Nauczyciele języków obcych w dobie przemian. Kraków: Impuls. 